\title{
STUDIES ON FORMULATION AND THE EFFECT OF FERMENTATION ON MILLET BASED COMPOSITE FLOUR RUSK
}

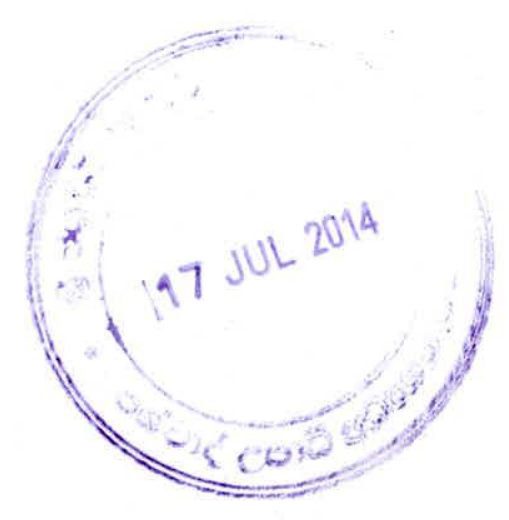

By

Bamunusinghage Varuni Samarasekara

Thesis submitted in partial fulfillment of the requirements for the degree of Master of Food Science and Technology, Department of Food Science and Technology , Faculty of Applied Science, University of Sri Jayawardenapura, Sri Lanka . 


\section{DECLARATION}

"The work of this thesis was carried out by me at the laboratory of the Department of Food science and Technology of University of Sri Jayawardenapura under the supervision of

Mrs. D. Rajapaksha, Senior Research Officer, Food Technology Division of the Industrial Technology Institute, Colombo and a report on this has not been submitted in whole or in part to any University or Institution for another degree or diploma"

Wamaraselcara

Bamunusinghage Varuni Samarasekara
$20 \cdot 03 \cdot 14$

Date 
I certify that the above statement made by the candidate is true and that this thesis is suitable for submission to the university for the purpose of evaluation

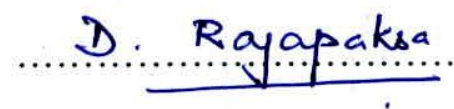

Mrs. D. Rajapaksha

Senior Research Officer

Food Technology Division

Industrial Technology Institute

Colombo 07

\section{$20^{\operatorname{m}}$ March 14}

Date 


\section{TABLE OF CONTENTS}

Table of Contents

Page

List of tables

i

List of figures

vi

vii

List of tables

viii

Acknowledgement

ix

Abstract

$\mathrm{x}$

CHAPTER 1 - INTRODCTION

1.1 Objectives

CHAPTER 2 - LITERATURE SURVEY

2.1 Cereals

2.2 Millets

2.2.1 Kurakkan

2.2.2 Meneri

4

2.2.3 Amu

2.2.4 Thanahal 5

2.2.5 Barnyard millet 6

2.2.6 Pearl millet 6

2.3 Nutritional composition of millets 7

2.3.1 Comparison with other major staple foods $\quad 7$

2.3.2 Comparison between Meneri and other millets $\quad 8$

2.4 Antrinutritional factors in millets $\quad 9$

2.4.1 Phytic acid 9

$\begin{array}{ll}\text { 2.4.2 Poly phenols and Tannins } & 10\end{array}$

2.4.2.1 Types of polyphenols and Tannins $\quad 10$

2.4.2.2 Effect of polyphenol on nutrition $\quad 11$

2.4.2.3 The method of Assay of total phenols $\quad 12$

2.5 Fermentation 12

2.5.1 Fermentation of cereals - beneficial effects 12 
2.5.2 Bio- chemical changes during fermentation

2.6.1 basic ingredients for making rusks and their functions

2.7.1 Requirements for a good source of protein

2.7.2 Protein quality

2.7.3 Dietary requirements

3.1 Sampling $\quad 20$

$\begin{array}{ll}3.2 \text { Processing treatments } & 20\end{array}$

3.2.1 Dehulling $\quad 20$

3.2.2. Fermentation of Meneri $\quad 20$

3.3 Chemical analysis ( Proximate Composition ) 20

3.3.1 Determination of moisture $\quad 20$

3.3.1.1 Materials $\quad 20$

3.3.1.2 Procedure 21

$\begin{array}{ll}\text { 3.3.1.3 Calculations } & 21\end{array}$

3.3.2 Determination of Fat ( free fat ) 21

3.3.2.1 Materials $\quad 21$

3.3.2.2 Method $\quad 22$

$\begin{array}{ll}\text { 3.3.2.3 Calculations } & 22\end{array}$

3.3.3 Determination of Protein 23

3.3.3.1 Materials $\quad 23$

3.3.3.2 Method 23

$\begin{array}{ll}\text { 3.3.3.3 Calculations } & 24\end{array}$

3.3.4 Determination of crude fiber $\quad 24$ 
3.3.4.1 Materials

3.3.4.2 Method 24

$\begin{array}{ll}\text { 3.3.4.3 Calculations } & 25\end{array}$

3.3.5 Determination of ash content $\quad 26$

$\begin{array}{ll}\text { 3.3.5.1 Materials } & 26\end{array}$

3.3.5.2 Method $\quad 26$

3.3.5.3 Calculations $\quad 26$

$\begin{array}{ll}\text { 3.3.6 Determination of Iron and calcium - } & 27\end{array}$

Atomic absorption method

$\begin{array}{ll}\text { 3.3.6.1 Materials } & 27\end{array}$

$\begin{array}{ll}\text { 3.3.6.2 Method } & 27\end{array}$

3.3.7 Determination of Total Polyphenols 28

$\begin{array}{ll}\text { 3.3.7.1 Materials } & 28\end{array}$

$\begin{array}{ll}\text { 3.3.7.2 Method } & 28\end{array}$

$\begin{array}{ll}\text { 3.3.7.3 Calculation } & 29\end{array}$

3.3.8 Determination of Carbohydrate( Carbohydrates by difference) 30

3.3.9 Determination of Energy value $\quad 30$

$\begin{array}{ll}3.4 \text { Preparation of the rusk } & 30\end{array}$

3.4.1 Wheat flour $\quad 30$

3.4.2 Preparation of the composite flour 30

$\begin{array}{ll}\text { 3.4.2.1 Materials } & 30\end{array}$

$\begin{array}{ll}\text { 3.4.2.1 Method } & 30\end{array}$

3.4.3 Selection of a suitable composite flour mixture $\quad 31$

3.4.3.1Raw materials 31

$\begin{array}{ll}\text { 3.4.3.2 Method } & 31\end{array}$

3.4.3.4 Selection of the flour mixture 34

3.4.4 Preparation of the rusks $\quad 34$

3.4.4.1 Preparation of the rusks -Trial $1 \quad 34$

3.4.4.2 Preparation of rusks - Trial $2 \quad 34$

3.4.4.3 Final formula for the production of the rusk 35 
3.5.1Materials $\quad 35$

$\begin{array}{ll}\text { 3.5.2Method } & 35\end{array}$

$\begin{array}{ll}3.6 \text { Sensory analysis } & 36\end{array}$

3.7 Proximate composition of the rusk 36

$\begin{array}{ll}\text { 3.8 Shelf life determination } & 36\end{array}$

4.1 Proximate composition, calcium, iron and total polyphenol levels of Meneri samples

4.2 Proximate composition, calcium, iron and total polyphenol levels of fermented Meneri samples

4.3 Fermentation studies - variation of $\mathrm{pH}$ during fermentation

4.4Formulation of the flour mixture for the preparation of rusks 43

4.5 Prooduction process of rusks $\quad 44$

4.5.1 Results of trial 1 45

4.5.2 Results of Trial $2 \quad 46$

$\begin{array}{ll}4.5 .3 \text { production of the rusks } & 46\end{array}$

$\begin{array}{ll}\text { 4.6 Sensory evaluation of rusks } & 47\end{array}$

4.6.1Results of Stastical analysis using Friedman's test $\quad 47$

4.6.1.1 Sensory analysis on colour of rusks 48

4.6.1.2 Sensory analysis on crispness of rusks 49

4.6.1.3 Sensory analysis on mouth feel of rusks 49

4.6.1.4 Sensory analysis on aftertaste of rusks $\quad 51$

4.6.2 Average values for sensory characteristics $\quad 51$

4.7 Analysis of the selected rusk for quality parameters 52

4.7.1 Proximate analysis of fermented meneri rusks $\quad 52$

4.7.2 Determination of minerals - iron and calcium 52 
4.7.3 Determination of Polyphenol content

4.7.4 Determination of the mass of a rusk

4.8 Contribution to the RDA value of Protein

4.8.1 For adults

4.8.2 For children and adolescents

4.8 Shelf life analysis 


\section{LIST OF TABLES}

Page

Table2.1 Nutrient content of the various millets with comparison to Rice 07 and Wheat

Table2.2 Nutrient content of various millets

Table3.1 Formulations of the flour mixture

Table3.2 Final formula for rusks

Table4.1 Proximate composition, $\mathrm{Ca}, \mathrm{Fe}$ and total polyphenol levels of Meneri

Table4.2 Proximate composition, $\mathrm{Ca}, \mathrm{Fe}$ and total polyphenol levels of fermented Meneri

Table4.3 Change in $\mathrm{pH}$ with time during fermentation

Table4.4 Characteristics of rusks prepared using different composite flour mixtures

Table4.5 Average values for the sensory characteristics

Table4.6 Proximate analysis for primary nutrients of rusks

Table4.7 Iron and Calcium contents of the rusks

Table4.8 Contribution to RDA of protein - for adults

Table4.9 Contribution to RDA of protein - for children and adolescents

Table4.10 Variation of moisture content of rusks with time 


\section{LIST OF FIGURES}

\section{Page}

Fig .2.1 Structure of flavones reported in millets

Fig 4.1 Trial preparation 1 ( after the initial baking )

Fig 4.2 Trial preparation 2 ( after the initial baking )

Fig 4.3 Rusks produced from fermented meneri flour and wheat flour mixture

Fig 4.4 Average values for the sensory characteristics 


\section{LIST OF GRAPHS}

Page

4.1 Friedman test results for colour

47

4.2 Friedman test results for crispness 48

4.3 Friedman test results for mouthfeel 49

$44 \quad$ Friedman test results for aftertaste 49 


\section{ACKNOWLEDGEMENT}

I wish to express my deepest gratitude to my supervisor Mrs. Damitha Rajapaksha, Senior Research Officer of the Food technology Division of Industrial Technology Institute, for her assistance, encouragement and generous support during the period of work.

I would like to acknowledge Prof. K.K.D.S.Ranaweera,head of the Department of Food Science and Technology, University of Sri Jayawardenapura and all the academic and non academic staff of the Department of Food Science and Technology, University of Sri Jayawardenapura for the help they have given in numerous ways .

My sincere thanks to the staff members of the Field Crop Research Development Institute at Mahailluppallama and Plant Genetic Resourcs Centre, Gannoruwa, Peradeniya.. I am grateful to Mr. H.Sirisena of Usgala, Suriyawewa who cultivated the Meneri (AC254) in his chena, enabling me to carry out this research.

Finally I wish to thank all my batch mates and my family for their encouragement and support during the study. 


\title{
STUDIES ON FORMULATION AND THE EFFECT OF FERMENTATION ON A MILLET BASED COMPOSITE FLOUR RUSK
}

\begin{abstract}
The major millet types grown in Sri Lanka are Kurakkan (Eleusine coracana), Meneri (Panicum miliaceum L ) and Thanahal (Setaria italica). The millets are known as minor cereals as they are small grain crops which are less common and cultivated in a smaller region of the country. These varieties are recommended to be grown in Sri Lanka by the Field Crop Research Development Institute at Mahailluppallama, as a source of energy and protein.
\end{abstract}

This study was undertaken to develop a ready to eat food item ( rusks ) using a blend of wheat flour and Meneri flour. The effect of fermentation on the nutrient composition and the polyphenol content was also studied. Meneri ( AC254) used for the study was obtained from Field Crop Research Development Institute at Mahailluppallama and also from Plant Genetic Resources Centre, Gannoruwa, Peradeniya .

Proximate analysis of both fermented Meneri flour and unprocessed Meneri flour was carried out using AOAC official methods .Fermented Meneri contained moisture $10.40 \pm 0.12 \%$, Carbohydrate $72.39 \%$, Protein $13.25 \pm 0.07 \%$ Fat $1.09 \pm 0.03 \%$, Crude fibre 1.70 $\pm 0.02 \%$, Ash $1.17 \pm 0.03 \%$ ( on dry basis ). Proximate analysis of unprocessed Meneri flour gave the following results . Moisture $7.80 \pm 0.03 \%$, Carbohydrate $75.40 \%$, Protein $11.9 \pm 0.13 \%$ Fat $1.47 \pm .01 \%$ Crude fibre $1.47 \pm .01 \%$, Ash $1.27 \pm 0.01 \%$ ( on dry basis ). Fermentation ( 48 hours) was observed to increase the Moisture and protein contents significantly $(\mathrm{P} \leq 0.05)$, and decreased the fat and crude fibre contents significantly.

$(\mathrm{P} \leq 0.05)$. There was no significant change in the ash content on fermentation.

The minerals iron and calcium were determined by Atomic absorption spectroscopy. The amount of iron in fermented Meneri flour was $7.32 \pm 0.04 \mathrm{mg} / 100 \mathrm{~g}$ and unprocessed 
Meneri flour had $5.22 \pm 0.13 \mathrm{mg} / 100 \mathrm{~g}$. The levels of iron in the two samples of Meneri flour were not significantly different $(P \geq 0.05)$. There was a significant difference between the amounts of calcium in the two samples $(P \leq 0.05)$. The fermented Meneri flour and unprocessed Meneri flour had calcium levels of $7.32 \pm 0.04 \mathrm{mg} / 100 \mathrm{~g}$ and $8.10 \pm 0.80 \mathrm{~g} /$ $100 \mathrm{~g}$ respectively.

The total polyphenol content was determined spectrophotometrically using Folin - Ciocalteu reagent. The total polyphenol content in unprocessed Meneri flour was $150.3 \pm 1.6 \mathrm{mg}$ tannic acid equivalents/ 100g). Fermented meneri flour had a total polyphenol content of $-115.5 \pm 0.85 \mathrm{mg}$ tannic acid equivalents/ $100 \mathrm{~g}$ ). There is a significant difference ( $\mathrm{P}$ $\leq 0.05$ ) between the total polyphenol contents of the two samples.

A flour formulation for the preparation of rusks was selected after carrying out several baking studies using different composite mixtures of Meneri flour and Wheat flour. The most accepeted flour formulation (40\% Meneri flour and $60 \%$ Wheat flour) was selected by sensory evaluation and by analysis of chemical composition. Both fermented Meneri flour and unprocessed Meneri flour were used for the preparation of the rusks.

The final product was selected after carrying out sensory evaluations on colour, crispness, mouth feel and aftertaste. The sensory attributes were evaluated using a five point hedonic scale. The rusks prepared with fermented Meneri flour was superior with respect to mouth feel and aftertaste. There was no significant difference observed for crispness and colour $(P \geq 0.05)$ between the two types of rusks.

The chemical composition and keeping quality of the selected final product ( $40 \%$ fermented Meneri flour and $60 \%$ Wheat flour ) was analyzed according to the AOAC official methods . The rusks contained Moisture $2.80 \%$, Carbohydrate $76.37 \%$, Protein $13.9 \%$, fat $3.80 \%$ Crude fibre $1.57 \%$, Ash $1.56 \%$ ( on dry basis ), iron $3.8 \mathrm{mg} / 100 \mathrm{~g}$ and calcium $11.4 \mathrm{mg}$ $/ 100 \mathrm{~g}$. The polyphenol content was $64 \mathrm{mg}$ tannic acid eq/ $100 \mathrm{~g}$. The energy value of the rusks was $395.28 \mathrm{kCal} / 100 \mathrm{~g}$. 


\section{CHAPTER 1}

\section{INTRODUCTION}

Millets are one of the oldest foods known to humans and one of the first cereal grains to be used for domestic cculinary purposes. Millets were first domesticated in Africa about five thousand years ago. There is evidence that this grain reached India three thousand years ago.

The use of millets in Sri Lanka goes back to many years. Kurakkan (Elucine coracana) and Meneri ( Panicum milaceum L. ) being the staple food of the Veddha community .Kurakkan and Meneri have been grown in Chena cultivations in the dry zone in Sri Lanka. These grains are drought resistant and can be stored without deterioration for many years .All food preparations made from rice flour can be made using Meneri flour .

The nutritional value of millets is comparable with other cereals . Both proso millet and foxtail millet are somewhat higher in protein than common varieties of rice, corn and oats . It is rich in vitamins and minerals .

However in Sri Lanka millets have limited utilization and are less popular . Meals and other preparations of millets have a strong flavor which is not generally appreciated by persons having access to blander grains such as wheat, rice and oats. The main reason for the poor sensory properties is due to the presence of significant amounts of antinutritional factors such as Phytates, Tannins and Polyphenols. Tannins and Polyphenols influence the colour and flavor. Phytates have long been recognized as a strong chelating agent of important minerals such as calcium, magnesium, iron and zinc. Traditional processing treatments such as soaking, dehulling, germination and fermentation are used to reduce the antinutritional factors, and thereby improving the nutritive value of these minor cereals .

The use of blends of wheat and millet flours in the manufacture of various food products is popular in African countries and in India. . Baby food ,snack foods beverages, breads, dietary foods and extruded products have been developed using composite flour mixtures of wheat and millets by simple processing techniques. The International Crops Research for Semi -Arid Tropics ( ICRISAT) is working on popularizing the millet based low cost, high protein and energy rich products . 